\title{
Review
}

\section{Macro-management of microRNAs in cell cycle progression of tumor cells and its implications in anti-cancer therapy}

\author{
Lin-hui LIANG, Xiang-huo HE* \\ State Key Laboratory of Oncogenes and Related Genes, Shanghai Cancer Institute, Renji Hospital, Shanghai Jiao Tong University \\ School of Medicine, Shanghai 200032, China
}

The cell cycle, which is precisely controlled by a number of regulators, including cyclins and cyclin-dependent kinases (CDKs), is crucial for the life cycle of mammals. Cell cycle dysregulation is implicated in many diseases, including cancer. Recently, compelling evidence has been found that microRNAs play important roles in the regulation of cell cycle progression by modulating the expression of cyclins, CDKs and other cell cycle regulators. Herein, the recent findings on the regulation of the cell cycle by microRNAs are summarized, and the potential implications of miRNAs in anti-cancer therapies are discussed.

Keywords: MicroRNA; cell cycle progression; cancer therapy

Acta Pharmacologica Sinica (2011) 32: 1311-1320; doi: 10.1038/aps.2011.103; published online 12 Sep 2011

\section{Introduction}

The cell cycle, which is involved in many cellular processes such as proliferation, development and differentiation, is a crucial process in mammals. In a normal cell, the maintenance of cell cycle fidelity is strictly controlled by surveillance proteins, including cyclins and cyclin-dependent kinases (CDKs). After receiving mitogenic signals, the cells exit from the $G_{0}$ phase and enter the $G_{1}$ phase. Subsequently, cyclin D binds to $\mathrm{CDK} 4$ and CDK6, leading to the partial inactivation of $\mathrm{Rb}$ family proteins. Inactivation of $\mathrm{Rb}$ proteins results in the transcription of E2F1-related genes. Cyclin E1, which is encoded by an early E2F1 responsive gene, then binds to CDK2 and completely inactivates $\mathrm{Rb}$ protein, driving the cells to enter the $S$ phase. When the cells enter the $S$ phase, cyclin A binds to CDK2 and promotes the phosphorylation of many proteins involved in DNA synthesis. Prophase is then initiated after cyclin A binds to CDK1. At the end of interphase, breakdown of the nuclear envelope leads to the interaction of cyclin B with CDK1, which in turn allows the cells to undergo mitosis. In addition to the positive regulation by cyclins/CDKs, the cell cycle is also controlled by negative regulatory proteins, such as CDK inhibitors, which mainly include two families: the INK4 and Cip/Kip families ${ }^{[1]}$. Additionally, cell cycle regulation is

\footnotetext{
* To whom correspondence should be addressed.

E-mail xhhe@shsci.org

Received 2011-04-09 Accepted 2011-07-05
}

monitored by many checkpoints, such as the ATM/ATR pathway $^{[2]}$. As summarized above, proper progression through the cell cycle is strictly monitored by various positive and negative surveillance factors. Improper progression through the cell cycle results in many diseases, including cancer. Indeed, the disruption of normal cell cycle progression is a very important event in the initiation and development of cancer. Cancer cells often show genomic instability, which is usually caused by cell cycle dysfunction and leads to unscheduled proliferation $^{[3]}$. Moreover, genomic instability predisposes cancer cells to acquire more genetic alterations, which contributes to a more aggressive cancer phenotype. Thus, understanding cell cycle dysregulation in cancers will facilitate the development of improved and novel anti-cancer therapies.

MicroRNAs (miRNAs) are small, non-coding RNAs that regulate gene expression mainly by binding to the 3 ' untranslated regions ( $3^{\prime}$-UTRs) of target genes ${ }^{[4]}$. After miRNAs bind to a target gene, the target protein is down-regulated owing to mRNA degradation or translation termination. Currently, there are 1424 known human microRNAs, and it is predicted that approximately $30 \%$ of human protein-coding genes are regulated by miRNAs ${ }^{[5]}$. In the past five years, compelling studies have demonstrated that miRNAs are involved in many physiological and pathological processes, such as cancer. In 2005, He L and co-workers found that expression of the miR-17-92 cluster was increased in B-cell lymphoma and cooperated with c-myc to accelerate tumor formation in $v i v o^{[6]}$. 
Additionally, Cimmino A et al demonstrated that miR-15 and miR-16 induced apoptosis by targeting BCL- $2^{[7]}$. These studies indicated that microRNAs can act as potent oncogenes or tumor suppressors and can regulate the progression of cancer. Since then, an increasing number of studies have clarified the role of miRNAs in cell cycle control, proliferation and tumor metastasis. In this review, we will focus on the regulation of tumor cell cycle progression by miRNAs, how miRNAs alter cell cycle regulatory networks and the implications of this regulation in anti-cancer therapy.

\section{The macro-management of miRNAs in cell cycle progres- sion}

Evidence for the importance of miRNAs in regulating the cell cycle originated in studies of the miRNA target gene lin $-4^{[8]}$, which acts to modify latent reiterative cell lineages and cell division in $C$ elegans. In the past five years, increasing evidence has indicated that miRNAs directly control cell cycle progression by targeting cell cycle regulators. Additionally, miRNAs indirectly control cell cycle progression by targeting signal transduction pathways. Therefore, miRNAs affect cell cycle progression by targeting various genes that span the cell cycle regulatory network.

\section{Let-7 family}

The let-7 miRNA was first discovered to be essential for development in $C$ elegans, possibly by targeting the lin- 41 gene $^{[8]}$. It was reported that let-7 is downregulated in human lung cancer, and enforced expression of let-7 in lung cancer cells inhibits proliferation ${ }^{[9]}$. A subsequent study indicated that let-7 not only inhibits proliferation but also alters the cell cycle progression of cancer cells ${ }^{[10]}$. In that study, Johnson et al demonstrated that let-7 overexpression retains cells in the $G_{1}$ phase and alters cell cycle-related pathways. CDK6, CDC25A, and cyclin D2 have been validated as direct downstream targets of let-7 in lung cancer cells. Schultz et al found reduced expression of let-7b in melanoma cells, and let-7b also delays the $G_{1} / S$ transition by down-regulating cyclin D1, cyclin D3, cyclin A, and CDK4 $4^{[11]}$. Another let-7 family member, let-7a, is down-regulated in prostate cancer and induces $\mathrm{G}_{1}$ arrest by reducing the levels of the downstream targets E2F2 and cyclin $\mathrm{D}^{[12]}$. In addition to regulating the $\mathrm{G}_{1} / \mathrm{S}$ transition, the let-7 family also affects the $G_{2} / M$ phase. In human primary fibroblasts, let-7 expression is reduced in the dividing cells. Ectopic expression of let-7 in fibroblast cells decreases proliferation and increases the cell fraction in the $\mathrm{G}_{2} / \mathrm{M}$ phase. Let-7 induces $\mathrm{G}_{2} / \mathrm{M}$ arrest by down-regulating the CDC34 protein, which then increases wee1 protein levels and subsequently increases the inhibitory phosphorylation of $\mathrm{CDC}^{[13]}$. In summary, the let-7 family members negatively control cell cycle regulators, which results in reduced proliferation and other cell-type specific phenotypes.

\section{miR-17-92 and miR-106b/25 clusters}

Another versatile miRNA family that controls the cell cycle includes the miR-17-92 and miR-106b/25 clusters. This
miRNA family is composed of three miRNA clusters located on three different chromosomes. The miRNAs include miR-17, miR-18a, miR-19a, miR-20a, miR-19b-1, and miR92a-1, which are encoded on chromosome 13; miR-106b, miR-93, and miR-25, encoded on chromosome 7; and miR106a, miR-18b, miR-20b, miR-19b-2, miR-92a-2, and miR363 , encoded on the $X$ chromosome. The miR-17-92 cluster is amplified in B-cell lymphoma, and enforced expression of miR-17-92 antagonizes c-myc-induced apoptosis and acts with c-myc to increase tumor development in a B-cell lymphoma animal model. These results indicate that the miR-17-92 cluster functions as an oncogene ${ }^{[6]}$. Expression of the miR-17-92 cluster is also elevated in lung cancer and promotes the proliferation of lung cancer cells ${ }^{[14]}$. Recently, miR-17-92 was found to be induced by c-myc and to promote tumor angiogenesis ${ }^{[15]}$. In addition to c-myc, miR-17-92 is induced by E2F transcription factors and forms a negative regulatory loop by directly targeting $\mathrm{E}_{2} \mathrm{Fs}^{[16,17]}$. As a potential mechanism of cancer cell cycle regulation by miR-17-92, it was reported that c-mycinduced miR-17 and miR-20a cooperate with the RB/E2F signaling pathway to control the accurate timing of the $G_{1} / S$ transition ${ }^{[18]}$. Cloonan et al reported that miR-17-5p regulates more than $20 \mathrm{G}_{1} / \mathrm{S}$ transition-related genes ${ }^{[19]}$, and RBL2 was identified as a functional downstream gene of miR-17-5 $p^{[20,}$ ${ }^{21]}$. It should be noted that the targets of miR-17-92 depended on the cellular context, which results in diverse functions of the miR-17-92 cluster in different cells. For example, in c-mycoverexpressing Raji cells, miR-17-19b-1 reduces the expression of Bim. In BCL-2-overexpressing SUDHL4 cells, miR-17-19b-1 decreases the expression of CDKN1A/p21 and facilitates the $\mathrm{G}_{1} / \mathrm{S}$ transition ${ }^{[22]}$. In contrast to the function of miR-17-19b-1 in SUDHL4 cells, miR-17/20a inhibits the $G_{1} / S$ transition in breast cancer cells by reducing the expression of cyclin $\mathrm{D} 1^{[23]}$. It has been reported that miR-17-92 regulates a set of $\mathrm{G}_{1} / \mathrm{S}$ transition-related genes, including pro-proliferation genes, such as cyclin D1 and E2F1, and anti-proliferation genes, such as CDKN1A (p21), PTEN, RB1, RBL1 (p107), and RBL2 $(\mathrm{p} 130)^{[24]}$. The dual regulation of pro-proliferation and antiproliferation target genes by miR-17-92 may explain the variation in the reported functions of miR-17-92.

In addition to the miR-17-92 cluster, E2F1 also regulates the expression of the miR-106b/25 cluster and is suppressed by the miR-106b/25 cluster, thereby forming a negative regulatory loop ${ }^{[25]}$. Moreover, up-regulation of the miR-106b/25 cluster impairs the transforming growth factor (TGF)- $\beta$ tumor suppressor pathway by targeting CDKN1A (p21 Waf1/ Cip1) and BCL-2L11 (Bim), which in turn reverses $\mathrm{G}_{1}$ arrest induced by the TGF-beta signal ${ }^{[25]}$. Therefore, up-regulation of the miR-106b/25 cluster negatively modulates the TGF-beta tumor suppressor pathway and facilitates the development of tumors.

\section{miR-34 family}

The miR-34 family includes important p53-responsive miRNAs, and when upregulated, the miRNAs induce p53-mediated processes, such as cell cycle arrest and apoptosis ${ }^{[26,27]}$. 
In human A549 cells, miR-34a induces $\mathrm{G}_{1}$ arrest by targeting cyclin D1 and CDK6, which in turn affects the phosphorylation of $\mathrm{Rb}$ protein ${ }^{[28]}$. In neuroblastoma, miR-34a reduces the expression of BCL-2 and MYCN to block the $G_{1} / S$ transition ${ }^{[29]}$. E2F3 is also a target of miR-34a in neuroblastoma ${ }^{[30]}$. However, in human glioma and medulloblastoma cells, miR-34a induces $\mathrm{G}_{1}$ arrest by reducing c-MET, Notch1, Notch2, and CDK6 ${ }^{[31]}$; in human astrocytes, however, overexpression of miR-34a does not alter cell cycle progression ${ }^{[31]}$. Another member of the miR-34 family, mir-34b, also regulates cell cycle regulators. In acute myeloid leukemia, miR-34b targets the CREB protein and decreases various CREB downstream proteins, such as BCL-2, cyclin A1, cyclin B1, cyclin D, nuclear factor-kappa B, Janus-activated kinase 1 and signal transducer and activator of transcription $3^{[32]}$. miR-34 also regulates cell cycle progression independent of the p53 signal. In p53-null K562 cells, phorbol esters induce miR-34a expression by activating an alternative phorbol ester-responsive promoter to produce a longer primiR-34a transcript. Additionally, enforced expression of miR$34 \mathrm{a}$ in $\mathrm{K} 562$ cells inhibits proliferation and $\mathrm{G}_{1} / \mathrm{S}$ transition by targeting CDK4 and CDK6 ${ }^{[33]}$. Another p53 family member, p63 positively regulates cell cycle progression by repressing the expression of miR34a and miR34 $c^{[34]}$. In the absence of p63, miR-34a and miR-34c are increased in primary keratinocytes and embryonic skin, with concomitant $G_{1}$ arrest and inhibition of the cell cycle regulators cyclin D1 and CDK $4^{[34]}$. Taken together, these data indicate that the miR-34 family modulates the expression of various cell cycle-related genes and is therefore important in the cell cycle progression of numerous cell types.

\section{Other miRNAs regulating cell cycle progression}

Cell cycle regulators are also modulated by many other miRNAs. One example is cyclin D1, which is regulated by miR$449 a^{[35]}, \operatorname{miR}-193 b^{[36]}, \operatorname{miR}-15 / 16^{[37-39]}, \operatorname{miR}-19 a^{[40]}, \operatorname{miR}-195^{[41]}$, and miR-302a ${ }^{[42]}$. The cyclin D1 binding proteins CDK4 and CDK6 are also regulated by a number of miRNAs, including $\operatorname{miR}-107^{[43]}, \operatorname{miR}-449 a^{[44]}, \operatorname{miR}-129^{[45]}, \operatorname{miR}-125 b^{[46]}, \operatorname{miR}-15 / 16^{[39]}$, $\operatorname{miR}-24^{[47]}$, miR-195 ${ }^{[41]}$, and miR-124a ${ }^{[48]}$. Another important $\mathrm{G}_{1} / \mathrm{S}$ regulator cyclin $\mathrm{E}$, is down-regulated by miR-16 ${ }^{[37]}$ and miR-195 ${ }^{[49]}$. In addition to the positive $G_{1} / S$ regulators, negative $G_{1} / S$ regulators are also targeted by various miRNAs. The CDK inhibitor p21 is targeted by miR-17-92 and miR$106 \mathrm{~b} / 93^{[22,25]}$ in addition to many other miRNAs ${ }^{[50,51]}$. The p27 and p57 proteins are regulated by $\mathrm{miR}-221 / 222^{[52,53]}$ and $\mathrm{miR}-$ $92 b^{[54]}$. The INK family member p16 is regulated by miR-24 ${ }^{[55]}$. The number of miRNAs regulating the entry and progression through $G_{2} / M$ is much fewer than those regulating the $G_{1} / S$ transition. The $\mathrm{G}_{2} / \mathrm{M}$-related cyclin $\mathrm{A}$ is targeted by let $-7^{[11]}$. miR-132/212 reduces the expression of RB1, which leads to an increase in E2F1 levels and $\mathrm{G}_{2} / \mathrm{M}$ arrest ${ }^{[56]}$. Dihydrofolate reductase (DHFR), an enzyme regulating the $S$ phase, is also regulated by miR-24 $4^{[57]}$ and $\mathrm{miR}-192^{[58]}$. In addition, PLK1, a critical regulator of many stages of mitosis, is targeted by miR$100^{[59]}$ and miR-593* [60]. Ectopic expression of miR-100 and miR-593* causes $G_{2} / M$ arrest and reduces proliferation. Wee
1 kinase, a nuclear protein that delays mitosis by negatively regulating the cyclinB-CDK1 complex, has been identified as a target of miR-128a, miR-155, and miR-516a-3 $p^{[61]}$. A summary of the miRNAs regulating the cell cycle is given in Table 1 and Figure 1.

\section{MicroRNAs add to the complexity of the cell cycle regulatory network}

As mentioned above, the cell cycle is monitored by an intricate network of positive and negative regulatory signaling pathways. An imbalance between the positive and negative regulatory pathways is common in cancers. With the addition of miRNAs as cell cycle regulators, new pathways have been discovered, and the context of the network has been remarkably enriched. Additionally, crosstalk between miRNAs and signaling pathways essential to cell cycle progression adds complexity to the cell cycle regulatory network.

\section{RAS/Raf/MEK/Erk signaling pathway}

When cells receive exogenous mitogenic signals, such as growth factor stimulation, the receptor tyrosine kinases (RTKs) will activate RAS and its downstream signaling pathways. One important signaling pathway induced by RAS activation is the Raf/MEK/Erk pathway, which leads to the activation of many cyclin/CDK complexes related to the $\mathrm{G}_{1} / \mathrm{S}$ transition. The hyperactivation of RAS is common in many tumors. In addition to mutation and constitutive mitogenic stimulation, many studies have indicated that tumor suppressor miRNAs targeting RAS are down-regulated in many cancers, which may contribute to the abnormal RAS activation. Let-7 family miRNAs ${ }^{[62,63]}$, miR-18* ${ }^{[64]}, \operatorname{miR}-143^{[65]}, \operatorname{miR}-181^{[66,67]}$, miR-96 ${ }^{[68]}$, and miR-214 ${ }^{[69]}$ directly target RAS and inhibit the proliferation and cell cycle progression of cancer cells, which are down-regulated in various cancers. The down-regulation of these miRNAs may be caused in part by the activation of the RAS signaling pathway, which forms a positive feedback loop. In pancreatic cancer cell lines, the expression of the miR$143 / 145$ cluster is frequently lost. Molecular analysis indicated that RREB1, a transcriptional factor downstream of RAS, can directly bind to the promoter of miR-143/145 and repress their expression ${ }^{[70]}$. Interestingly, RAS and RREB1 were found to be targets of miR-143 and miR-145, respectively. Thus, in pancreatic cancer, activation of RAS activates RREB1, which in turn represses the expression of the miR-143/145 cluster. The repression of miR-143/145 in turn potentiates RAS signaling, which forms a feed forward circuit. Moreover, some molecules downstream of RAS/MAPK/Erk, such as c-myc, cyclin D2, and CDK6, are also repressed by the miR-143/145 cluster $^{[71]}$. In addition to tumor suppressive miRNAs, RAS signaling also controls the expression of tumor-promoting miRNAs to facilitate its biological functions. miR-21 is a direct target of AP-1, a transcription factor downstream of the RAS/MAPK/ Erk pathway. miR-21 inhibits the expression of several molecules that negatively regulate the RAS/MAPK/Erk pathway, such as Btg2, Spry1, and spry $2^{[72]}$.

In addition to the regulation of specific miRNAs, the RAS/ 


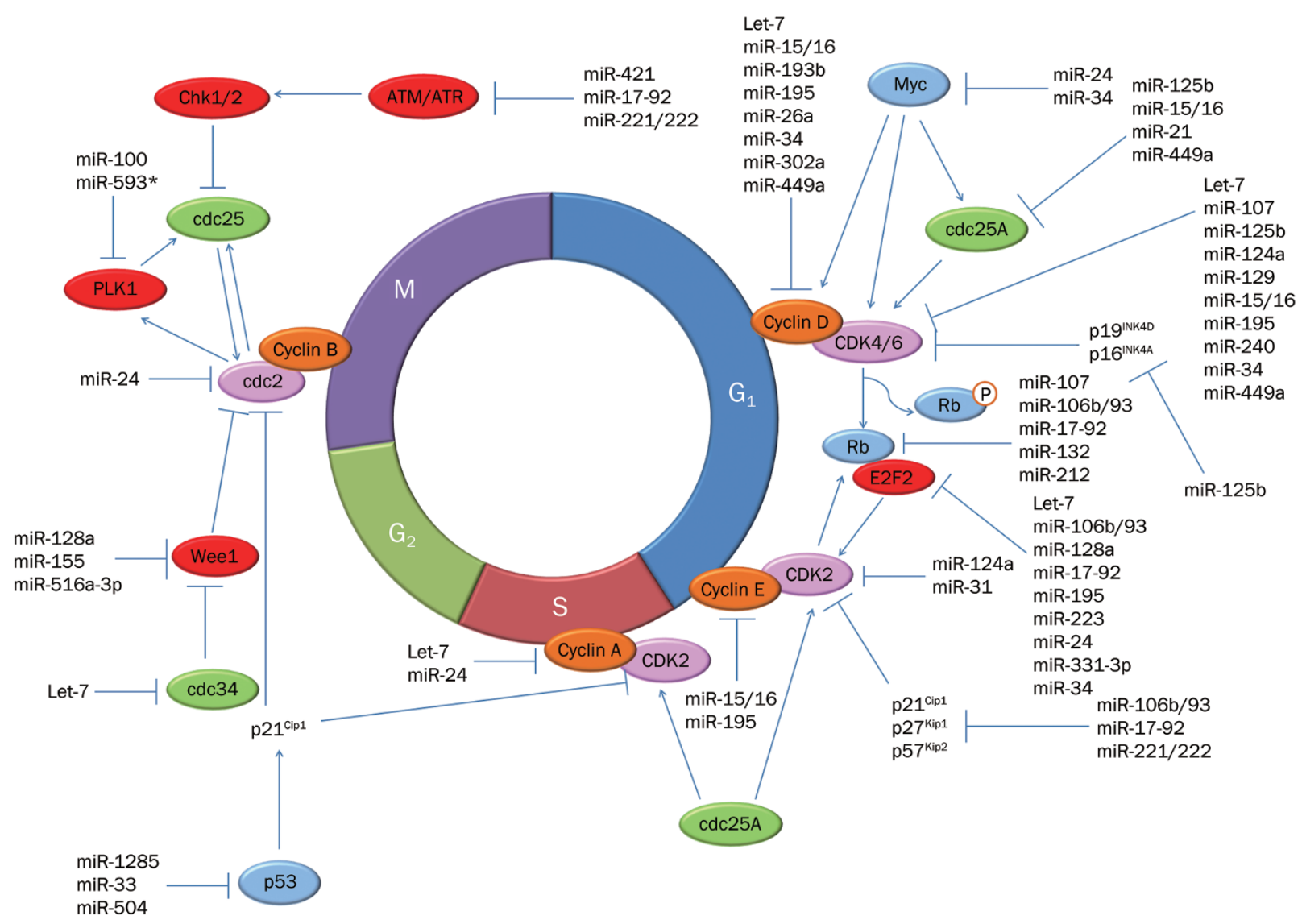

Figure 1. MicroRNAs in the control of cell cycle progression.

MAPK/Erk pathway also can control the expression of all miRNAs through phosphorylation of the HIV TAR RNA binding protein (TRBP), a critical protein of the miRNA generating complex ${ }^{[73]}$. The phosphorylation of TRBP by MAPK/Erk signaling enhances the expression of proliferation-promoting miRNAs and represses the expression of the let-7 tumor suppressor family. Together, these studies suggest that the RAS pathway can interact with the miRNA network to exert its biological functions.

\section{PI3K/AKT pathway}

The PI3K/AKT pathway is another important signaling cascade induced in response to mitogenic stimulation. PI3K/ AKT can transduce multiple extracellular signals during $\mathrm{G}_{1}$ and induce the cell to commit to DNA replication and division. In cancers, the aberrant activation of the PI3K/AKT pathway results in the up-regulation of cyclin D1, activation of the CDK2/cyclin E complex and down-regulation of p21 and p27, coordinately promoting cell cycle progression and the uncontrolled proliferation of cancer cells. PTEN and SHIP are negative regulators of the PI3K/AKT pathway. Many members of the PI3K/AKT pathway are regulated by miRNAs. miR-29a and miR-126 target the p85a and p $85 \beta$ subunits of PI3K ${ }^{[74,75]}$, respectively. The down-regulation of miR-126 in colon cancer is associated with the up-regulation of the $p 85 \beta$ subunit, which induces the phosphorylation of AKT and promotes the proliferation of colon cancer cells ${ }^{[75]}$. The AKT family is also regulated by miRNAs. For example, AKT1 is suppressed by miR$149^{*}{ }^{[76]}$, AKT2 is suppressed by miR-184 and miR-150 $0^{[77,78]}$, and AKT3 is suppressed by the miR-15/16 cluster ${ }^{[79]}$. PTEN is an important tumor suppressor that antagonizes PI3K activity by inhibiting the transformation of PIP2 to PIP3. In cancers, the expression of PTEN is repressed by many oncogenic miRNAs, including miR-21 ${ }^{[80,81]}, \operatorname{miR}-221 / 2^{[82]}$, miR-301 ${ }^{[83]}, \operatorname{miR}-144^{[84]}$, miR-136 $6^{[84]}$, and miR-19 ${ }^{[85]}$. SHIP is another lipid phosphatase that inhibits the generation of PIP3. The expression of SHIP can be suppressed by miR-155 in leukemia and lymphoma ${ }^{[86]}$. The down-regulation of SHIP and up-regulation of miR-155 initiates a series of events that lead to leukemia/lymphoma in a transgenic mouse model. Furthermore, the reduction of SHIP by miR-155 activates PI3K/AKT activation ${ }^{[87]}$. mTOR is a direct target of PI3K/AKT activation, which is activated by AKT phosphorylation. The activation of mTOR promotes the translation of cell cycle-related proteins, such as c-myc, and represses the expression of p21 and p27. In src-transformed tumor cells, miR-99a is down-regulated, which results in the up-regulation of $\mathrm{mTOR}^{[88]}$. Moreover, the expression of miR99a is inversely correlated with mTOR expression in lung cancer, and the re-expression of miR-99a in cancer cells inhibited the growth of tumors. Two other miRNAs that target mTOR 
Table 1. MicroRNAs and targeted cell cycle regulators.

\begin{tabular}{|c|c|c|}
\hline miR-124a & CDK2, CDK6 & 48 \\
\hline miR-107 & CDK6, RBL2 & 43 \\
\hline miR-137 & $\mathrm{CDC} 42$ & 121 \\
\hline miR-26a & Cyclin D1, Cyclin D2 & 112 \\
\hline miR-449a & Cyclin D1, CDK6, CDC25A & 35,44 \\
\hline miR-33 & p53 & 123 \\
\hline miR-193b & Cyclin D1 & 36 \\
\hline miR-221/2 & p27, p57, PTEN & 52,53 \\
\hline miR-331-3p & E2F1 & 124 \\
\hline miR-125b & CDKN2A, CDK6, CDC25A & 46 \\
\hline miR-34 & c-myc, Cyclin D1, CDK4, CDK6, E2F3, MYCN & $28-34$ \\
\hline miR-421 & ATM & 126 \\
\hline miR-223 & E2F1 & 94 \\
\hline miR-15/16 & Cyclin E1, Cyclin D1, Cyclin D2, Cyclin D3, CDC25A, c-myb, CDK6 & $37-39$ \\
\hline miR-21 & $\mathrm{CDC} 25 \mathrm{~A}$ & 127 \\
\hline miR-24 & E2F2, MYC, CCNA2, CDC2, CDK4 & 47,57 \\
\hline miR-100 & PLK1 & 59 \\
\hline miR-195 & CDK6, Cyclin D1, E2F3, Cyclin E1 & 41 \\
\hline miR-128a & E2F3a, Wee 1 & 61,128 \\
\hline miR-302a & Cyclin D1 & 42 \\
\hline
\end{tabular}

are miR-101 and miR-199a-3p, which suppress the expression of mTOR in lymphoma ${ }^{[89]}$ and hepatocarcinoma ${ }^{[90]}$, respectively.

\section{Myc and E2F family}

Myc is a transcription factor that integrates various extracellular signals and initiates transcriptional events to control proliferation, apoptosis and cell cycle progression. The dysregulation of myc is a common event in cancer development. In recent years, studies on miRNAs in the myc regulatory network have contributed to the understanding of the mechanism of myc activities. As a transcription factor, myc regulates the expression of many miRNAs ${ }^{[91]}$. It has been determined that myc-induced miRNAs directly participate in the down-regulation of myc-repressed genes. For instance, myc activation induces the expression of miR-221 and miR-222, which target p27 and p57. p27 and p57 are known to be repressed by myc. Thus, myc-induced miRNAs can interact with myc target genes to regulate cell cycle progression. In addition to regulating the miRNAs, myc is also directly targeted by miRNAs. In neuroblastoma, let-7e and miR-101 directly target the 3'-UTR, repress the expression of myc and inhibit the growth of tumor cells ${ }^{[92]}$. In non-small cell lung cancer, miR-145 inhibits proliferation and the $\mathrm{G}_{1} / \mathrm{S}$ transition by directly targeting c-myc ${ }^{[93]}$.

The E2F family members are direct targets of myc and regulate the expression of many genes controlling cell cycle progression. As mentioned above, the expression of the E2F family members is tightly controlled by the miR-17-92 family. The interaction between the miR-17-92 and E2F family members is complex. E2F1, E2F2, and E2F3 directly bind to the promoter of miR-20a and activate its transcription; however, miR-20a modulates the translation of E2F2 and E2F3, which suggests an autoregulatory feedback loop between the E2F family members and miR-20a ${ }^{[16]}$. The rest of the members of the miR17-92 and miR-106b/93 clusters also interact with the E2F family members and form autoregulatory feedback loops ${ }^{[17,25]}$. In addition to the miR-17-92 family members, E2F1 also binds to the promoter of miR-223 and represses its transcription, and E2F1 is also targeted by miR-223 $3^{[94]}$.

\section{p53 network}

p53 is one of the central players in the response to DNA dam- 
age and other cellular stresses. p53 is a tumor suppressor that is frequently deleted and/or mutated in tumors. When cells encounter genotoxic insults, p53 controls the transcription of many target genes, among which p21 is the major response molecule that induces cell cycle arrest. The miR-34 family members are direct targets of $\mathrm{p} 53^{[26,27]}$ and coordinate with p53 to suppress cell cycle progression and tumor growth. miR-107 is another target of $\mathrm{p} 53^{[95]}$. p53 can bind to the promoter of PANK1, the host gene of miR-107, and activate the transcription of PANK1 and miR-107. Interestingly, miR-107 suppresses the expression of two important $\mathrm{G}_{1} / \mathrm{S}$ regulators, CDK6 and RBL2. These studies show that miRNAs act as important players in the $\mathrm{p} 53$ network.

\section{Implications of cell cycle-related miRNAs in anti-cancer therapies}

Cell cycle-related miRNAs can act as oncogenes or tumor suppressors

Cell cycle deregulation and the resulting uncontrolled proliferation is one of the hallmarks of cancer. miRNAs have been shown to be crucial regulators of cell cycle progression, and aberrant expression of miRNAs is universal in human cancer. The first evidence of an aberrantly expressed miRNA was the miR-15/16 cluster, which is frequently deleted and/or downregulated in chronic lymphocytic leukemia (CLL) ${ }^{[96]}$. Through microarray technology, the miRNA expression profiles of lung ${ }^{[97]}$, liver ${ }^{[98,99]}$, breast ${ }^{[100]}$, colon ${ }^{[101,102]}$ and gastric cancer ${ }^{[103]}$ have been reported, and the results indicate that miRNAs are abnormally expressed in various cancers. Many cell cyclerelated miRNAs are specifically deregulated in cancer and function as oncogenes or tumor suppressors. It has been reported that the miR-17-92 cluster is frequently amplified ${ }^{[14,15]}$, and let-7 is frequently down-regulated ${ }^{[9,104]}$ in various cancers. miR-17-92 exerts oncogenic functions through positively regulating cell cycle-related proteins, including p21, p63, p57, and RBL2 ${ }^{[18-21]}$, whereas let-7 exerts its tumor suppressive function by down-regulating RAS, cyclins and CDK4 $4^{[8-11]}$. miR-21 is activated by RAS signaling and suppressed by several negative regulators of RAS signaling and the PI3K/AKT pathway, which in turn potentiates RAS activation and PI3K/AKT activities $^{[72]}$. The crosstalk between miR-21 and cell cycle regulation contributes to the development of a cancer phenotype. In summary, the cell cycle-related miRNAs can act as oncogenes or tumor suppressors by affecting cell cycle progression, which causes uncontrolled proliferation and more aggressive cancer phenotypes.

miRNAs may serve as therapeutic targets/candidates in cancer As oncogenes or tumor suppressors, cell cycle-related miRNAs may serve as therapeutic targets in cancers. By specific inhibition or selective re-introduction of miRNAs in cancers, miRNAs may have therapeutic effects. Approaches to the delivery of miRNAs in vivo include anti-miRNA oligonucleotides, antagomiRs, locked nucleic acid (LNA), miRNA sponges and nanoparticles, which each have their advantages and disad- vantages that have been elegantly reviewed elsewhere ${ }^{[105]}$. Importantly, some miRNAs have been shown to suppress tumor growth in vitro and in vivo. Let-7 inhibits the proliferation of hepatocellular carcinoma cells $(\mathrm{HCC})^{[106]}$, prostate cancer cells ${ }^{[12]}$, lung cancer cells ${ }^{[107]}$ and melanoma cells ${ }^{[11]}$ in vitro and the tumor growth of lung cancer ${ }^{[108]}$ and breast cancer ${ }^{[109]}$ in vivo. Therapeutic studies on miRNAs in vivo have revealed promising results. miR-21 is up-regulated by RAS in vitro and in vivo and is frequently overexpressed in human cancers. LNA directed against miR-21 reduced tumor growth in vivo ${ }^{[110]}$, which suggests a therapeutic role for anti-miR-21 in treating cancers. In addition, miR-16, which is frequently deleted and/ or down-regulated in human cancers, significantly inhibits prostate tumor growth in vivo when delivered by atelocollagen via tail vein injection ${ }^{[111]}$. These results indicate that the delivery of miR-16 could be used to treat patients with advanced prostate cancer. Notably, miR-26a is down-regulated in HCC, and the restoration of miR-26a in vitro induces cell cycle arrest by targeting cyclin D2 and cyclin E2. Intriguingly, the delivery of miR-26a using adeno-associated virus (AAV) inhibits the proliferation of cancer cells, induces tumor-specific apoptosis and results in dramatic protection from disease progression without toxicity ${ }^{[112]}$. Together, these in vitro and in vivo studies suggest that miRNAs can be targeted or directly delivered in vivo to suppress tumor growth, which may provide new strategies for developing next-generation anti-cancer therapeutics.

miRNAs are also associated with chemosensitivity and radiation sensitivity. miR-221/222 are overexpressed in fulvestrant-resistant breast cancer cells and are associated with the acquisition of fulvestrant resistance ${ }^{[113]}$. Furthermore, up-regulation of miR-221/222 in breast cancer cells also causes tamoxifen resistance by targeting $\mathrm{p} 27^{[114]}$. miR-221/222 is a promising candidate for breast cancer with chemoresistance. Another miRNA that has been shown to be involved in chemoresistance is miR-21. miR-21-transfected HCC cells are resistant to 5 -fluorouracil/interferon- $\mathrm{a}^{[115]}$, which suggests that anti-miR-21 may increase the chemosensitivity of cancer cells. Indeed, anti-miR-21 improves the cytotoxicity induced by 5 -FU in glioblastoma cells ${ }^{[116]}$. Anti-miR-21 also increases the chemosensitivity of cells to arsenic trioxide ${ }^{[117]}$ and taxol ${ }^{[118]}$. These findings suggest that anti-miR-21 could be used in combination with chemical reagents to increase the cytotoxic effects of cancer therapeutics.

miRNAs are also involved in the radiation sensitivity of cancers. In prostate cancer, multiple miRNAs, including miR106b, have demonstrated altered expression in response to radiation $^{[119]}$. The up-regulation of miR-106b in prostate cancer overrides p21-activated cell cycle arrest and growth inhibition induced by radiation ${ }^{[119]}$, providing a potential target for radiation-resistant prostate cancer. In contrast to miR-106b, miR-101 sensitizes tumor cells to radiation in vitro and in vivo by targeting DNA-PKCs and $\mathrm{ATM}^{[120]}$. Collectively, studies on the involvement of miRNAs in chemo- and radio resistance and sensitivity provide new targets and candidates for cancer treatment. 


\section{Conclusion}

Herein, we summarized the current understanding of miRNAs in regulating cell cycle progression. Many cell cycle regulatory proteins are regulated by miRNAs, and these proteins also control the expression of miRNAs, which display a complex interaction network. The deregulation of this network is tightly associated with the progression of human cancers. The discovery and thorough understanding of this complicated network will open an avenue for developing novel, promising therapeutics for the treatment of cancer.

\section{Acknowledgements}

This work was partially supported by the National Natural Science Foundation of China (№ 91029728 and 81071637), the Science \& Technology Commission of Shanghai Municipality (10JC1414200) and the Shanghai Rising-Star Program Funds (11QA1406200). We thank Jie Ding for artwork preparation and Jian Yao for manuscript editing. We apologize to those colleagues who have contributed to this exciting field but whose work could not be cited because of space limitations.

\section{References}

1 CJ Sherr, JM Roberts. CDK inhibitors: positive and negative regulators of G1-phase progression. Genes Dev 1999; 13: 1501-12.

2 Yang J, Xu ZP, Huang Y, Hamrick HE, Duerksen-Hughes PJ, Yu YN. ATM and ATR: sensing DNA damage. World J Gastroenterol 2004; 10: $155-60$.

3 Malumbres M, Barbacid M. Cell cycle, CDKs and cancer: a changing paradigm. Nat Rev Cancer 2009; 9: 153-66.

4 L He, GJ Hannon, MicroRNAs: small RNAs with a big role in gene regulation. Nat Rev Genet 2004; 5: 522-31.

5 Friedman RC, Farh KK, Burge CB, Bartel DP. Most mammalian mRNAs are conserved targets of microRNAs. Genome Res 2009; 19 : 92-105.

6 He L, Thomson JM, Hemann MT, Hernando-Monge E, Mu D, Goodson $\mathrm{S}$, et al. A microRNA polycistron as a potential human oncogene. Nature 2005; 435: 828-33.

7 Cimmino A, Calin GA, Fabbri M, Iorio MV, Ferracin M, Shimizu M, et al. miR-15 and miR-16 induce apoptosis by targeting BCL2. Proc Natl Acad Sci U S A 2005; 102: 13944-9.

8 Reinhart BJ, Slack FJ, Basson M, Pasquinelli AE, Bettinger JC, Rougvie $\mathrm{AE}$, et al. The 21-nucleotide let-7 RNA regulates developmental timing in Caenorhabditis elegans. Nature 2000; 403: 901-6.

9 Takamizawa J, Konishi H, Yanagisawa K, Tomida S, Osada H, Endoh $\mathrm{H}$, et al. Reduced expression of the let-7 microRNAs in human lung cancers in association with shortened postoperative survival. Cancer Res 2004; 64: 3753-6.

10 Johnson CD, Esquela-Kerscher A, Stefani G, Byrom M, Kelnar K, Ovcharenko $D$, et al. The let-7 microRNA represses cell proliferation pathways in human cells. Cancer Res 2007; 67: 7713-22.

11 Schultz J, Lorenz P, Gross G, Ibrahim S, Kunz M. MicroRNA let-7b targets important cell cycle molecules in malignant melanoma cells and interferes with anchorage-independent growth. Cell Res 2008; 18: 549-57.

12 Dong Q, Meng P, Wang T, Qin W, Qin W, Wang F, et al. MicroRNA let$7 a$ inhibits proliferation of human prostate cancer cells in vitro and in vivo by targeting E2F2 and CCND2. PLoS One 2010; 5: e10147.

13 Legesse-Miller A, Elemento O, Pfau SJ, Forman JJ, Tavazoie S, Coller HA. Let-7 overexpression leads to an increased fraction of cells in
$\mathrm{G}_{2} / \mathrm{M}$, direct down-regulation of Cdc34, and stabilization of Wee1 kinase in primary fibroblasts. J Biol Chem 2009; 284: 6605-9.

14 Hayashita Y, Osada H, Tatematsu Y, Yamada H, Yanagisawa $\mathrm{K}$, Tomida $\mathrm{S}$, et al. A polycistronic microRNA cluster, miR-1792 , is overexpressed in human lung cancers and enhances cell proliferation. Cancer Res 2005 ; 65: 9628-32.

15 Dews M, Homayouni A, Yu D, Murphy D, Sevignani C, Wentzel E, et al. Augmentation of tumor angiogenesis by a Myc-activated microRNA cluster. Nat Genet 2006; 38: 1060-5.

16 Sylvestre Y, De Guire V, Querido E, Mukhopadhyay UK, Bourdeau V, Major F, et al. An E2F/miR-20a autoregulatory feedback loop. J Biol Chem 2007; 282: 2135-43.

17 Woods K, Thomson JM, Hammond SM. Direct regulation of an oncogenic micro-RNA cluster by E2F transcription factors. J Biol Chem 2007; 282: 2130-4.

18 Pickering MT, Stadler BM, Kowalik TF. miR-17 and miR-20a temper an $E 2 F 1$-induced $G_{1}$ checkpoint to regulate cell cycle progression. Oncogene 2009; 28: 140-5.

19 Cloonan N, Brown MK, Steptoe AL, Wani S, Chan WL, Forrest AR, et al. The miR-17-5p microRNA is a key regulator of the $G_{1} / S$ phase cell cycle transition. Genome Biol 2008; 9: R127.

20 Lu Y, Thomson JM, Wong HY, Hammond SM, Hogan BL. Transgenic over-expression of the microRNA miR-17-92 cluster promotes proliferation and inhibits differentiation of lung epithelial progenitor cells. Dev Biol 2007; 310: 442-53.

21 Wang Q, Li YC, Wang J, Kong J, Qi Y, Quigg RJ, et al. miR-17-92 cluster accelerates adipocyte differentiation by negatively regulating tumor-suppressor Rb2/p130. Proc Natl Acad Sci U S A 2008; 105: 2889-94.

22 Inomata M, Tagawa H, Guo YM, Kameoka Y, Takahashi N, Sawada K. MicroRNA-17-92 down-regulates expression of distinct targets in different B-cell lymphoma subtypes. Blood 2009; 113: 396-402.

23 Yu Z, Wang C, Wang M, Li Z, Casimiro MC, Liu M, et al. A cyclin D1/ microRNA 17/20 regulatory feedback loop in control of breast cancer cell proliferation. J Cell Biol 2008; 182: 509-17.

24 Trompeter HI, Abbad H, Iwaniuk KM, Hafner M, Renwick N, Tuschl T, et al. MicroRNAs MiR-17, MiR-20a, and MiR-106b act in concert to modulate E2F activity on cell cycle arrest during neuronal lineage differentiation of USSC. PLoS One 2011; 6: e16138.

25 Petrocca F, Visone R, Onelli MR, Shah MH, Nicoloso MS, de Martino I, et al. E2F1-regulated microRNAs impair TGFbeta-dependent cellcycle arrest and apoptosis in gastric cancer. Cancer Cell 2008; 13 : 272-86.

26 He L, He X, Lim LP, de Stanchina E, Xuan Z, Liang Y, et al. A microRNA component of the p53 tumour suppressor network. Nature 2007; 447: 1130-4.

27 Chang TC, Wentzel EA, Kent OA, Ramachandran K, Mullendore M, Lee $\mathrm{KH}$, et al. Transactivation of miR-34a by p53 broadly influences gene expression and promotes apoptosis. Mol Cell 2007; 26: 74552.

28 Sun F, Fu H, Liu Q, Tie Y, Zhu J, Xing R, et al. Downregulation of CCND1 and CDK 6 by miR-34a induces cell cycle arrest. FEBS Lett 2008; 582: 1564-8.

29 Cole KA, Attiyeh EF, Mosse YP, Laquaglia MJ, Diskin SJ, Brodeur GM, et al. A functional screen identifies miR-34a as a candidate neuroblastoma tumor suppressor gene. Mol Cancer Res 2008; 6: 73542.

30 Welch C, Chen Y, Stallings RL. MicroRNA-34a functions as a potential tumor suppressor by inducing apoptosis in neuroblastoma cells. Oncogene 2007; 26: 5017-22.

31 Li Y, Guessous F, Zhang Y, Dipierro C, Kefas B, Johnson E, et al. 
MicroRNA-34a inhibits glioblastoma growth by targeting multiple oncogenes. Cancer Res 2009; 69: 7569-76.

32 Pigazzi M, Manara E, Baron E, Basso G. miR-34b targets cyclic AMP-responsive element binding protein in acute myeloid leukemia. Cancer Res 2009; 69: 2471-8.

33 Navarro F, Gutman D, Meire E, Cáceres M, Rigoutsos I, Bentwich Z, et al. miR-34a contributes to megakaryocytic differentiation of K562 cells independently of p53. Blood 2009; 114: 2181-92.

34 Antonini D, Russo MT, De Rosa L, Gorrese M, Del Vecchio L, Missero C. Transcriptional repression of miR-34 family contributes to p63mediated cell cycle progression in epidermal cells. J Invest Dermatol 2010; 130: 1249-57.

35 Noonan EJ, Place RF, Basak S, Pookot D, Li LC. miR-449a causes Rbdependent cell cycle arrest and senescence in prostate cancer cells. Oncotarget 2010; 1: 349-58.

36 Xu C, Liu S, Fu H, Li S, Tie Y, Zhu J, et al. MicroRNA-193b regulates proliferation, migration and invasion in human hepatocellular carcinoma cells. Eur J Cancer 2010; 46: 2828-36.

37 Balakrishnan A, Stearns AT, Park PJ, Dreyfuss JM, Ashley SW, Rhoads $\mathrm{DB}$, et al. MicroRNA miR-16 is anti-proliferative in enterocytes and exhibits diurnal rhythmicity in intestinal crypts. Exp Cell Res 2010; 316: 3512-21.

38 Bandi N, Zbinden S, Gugger M, Arnold M, Kocher V, Hasan L, et al. miR-15a and miR-16 are implicated in cell cycle regulation in a Rbdependent manner and are frequently deleted or down-regulated in non-small cell lung cancer. Cancer Res 2009; 69: 5553-9.

39 Liu Q, Fu H, Sun F, Zhang H, Tie Y, Zhu J, et al. miR-16 family induces cell cycle arrest by regulating multiple cell cycle genes. Nucleic Acids Res 2008; 36: 5391-404.

40 Qin X, Wang X, Wang Y, Tang Z, Cui Q, Xi J, et al. MicroRNA-19a mediates the suppressive effect of laminar flow on cyclin D1 expression in human umbilical vein endothelial cells. Proc Natl Acad Sci U S A 2010; 107: 3240-4.

41 Xu T, Zhu Y, Xiong Y, Ge YY, Yun JP, Zhuang SM. MicroRNA-195 suppresses tumorigenicity and regulates $G_{1} / S$ transition of human hepatocellular carcinoma cells. Hepatology 2009; 50: 113-21.

42 Card DA, Hebbar PB, Li L, Trotter KW, Komatsu Y, Mishina Y, et al. Oct4/Sox2-regulated miR-302 targets cyclin D1 in human embryonic stem cells. Mol Cell Biol 2008; 28: 6426-38.

43 Feng $\mathrm{L}$, Xie $\mathrm{Y}$, Zhang $\mathrm{H}$, Wu Y. miR-107 targets cyclin-dependent kinase 6 expression, induces cell cycle $G_{1}$ arrest and inhibits invasion in gastric cancer cells. Med Oncol 2011. DOI: 10.1007/s12032-0119823-1.

44 Yang X, Feng M, Jiang X, Wu Z, Li Z, Aau M, et al. miR-449a and miR-449b are direct transcriptional targets of E2F1 and negatively regulate $\mathrm{pRb}-\mathrm{E} 2 \mathrm{~F} 1$ activity through a feedback loop by targeting CDK6 and CDC25A. Genes Dev 2009; 23: 2388-93.

45 Wu J, Qian J, Li C, Kwok L, Cheng F, Liu P. miR-129 regulates cell proliferation by downregulating Cdk6 expression. Cell Cycle 2010; 9: $1809-18$.

46 Shi L, Zhang J, Pan T, Zhou J, Gong W, Liu N, et al. MiR-125b is critical for the suppression of human U251 glioma stem cell proliferation. Brain Res 2010; 1312: 120-6.

47 Lal A, Navarro F, Maher CA, Maliszewski LE, Yan N, O'Day E, et al. MiR-24 inhibits cell proliferation by targeting E2F2, MYC, and other cell-cycle genes via binding to "seedless" 3'UTR microRNA recognition elements. Mol Cell 2009; 35: 610-25.

48 Agirre X, Vilas-Zornoza A, Jiménez-Velasco A, Martin-Subero Jl, Cordeu L, Gárate L, et al. Epigenetic silencing of the tumor suppressor microRNA Hsa-miR-124a regulates CDK6 expression and confers a poor prognosis in acute lymphoblastic leukemia. Cancer Res 2009;
69: 4443-53.

49 Sekiya Y, Ogawa T, lizuka M, Yoshizato K, Ikeda K, Kawada N. Downregulation of cyclin E1 expression by microRNA-195 accounts for interferon- $\beta$-induced inhibition of hepatic stellate cell proliferation. J Cell Physiol 2011; 226: 2535-42.

50 Borgdorff V, Lleonart ME, Bishop CL, Fessart D, Bergin AH, Overhoff $\mathrm{MG}$, et al. Multiple microRNAs rescue from Ras-induced senescence by inhibiting p21 Waf1/cip1. Oncogene 2010; 29: 2262-71.

51 Wu S, Huang S, Ding J, Zhao Y, Liang L, Liu T, et al. Multiple microRNAs modulate $\mathrm{p} 21^{\text {Cip } 1 / \text { Waf1 }}$ expression by directly targeting its $3^{\prime}$ untranslated region. Oncogene 2010; 29: 2302-8.

52 Dai R, Li J, Liu Y, Yan D, Chen S, Duan C, et al. miR-221/222 suppression protects against endoplasmic reticulum stress-induced apoptosis via p27(Kip1)- and MEK/ERK-mediated cell cycle regulation. Biol Chem 2010; 391: 791-801.

53 Qian K, Hu L, Chen H, Li H, Liu N, Li Y, et al. Hsa-miR-222 is involved in differentiation of endometrial stromal cells in vitro. Endocrinology 2009; 150: 4734-43.

54 Sengupta S, Nie J, Wagner RJ, Yang C, Stewart R, Thomson JA. MicroRNA $92 b$ controls the $G_{1} / S$ checkpoint gene $p 57$ in human embryonic stem cells. Stem Cells 2009; 27: 1524-8.

55 Lal A, Kim HH, Abdelmohsen K, Kuwano Y, Pullmann R Jr, Srikantan $\mathrm{S}$, et al. p16(INK4a) translation suppressed by miR-24. PLoS One 2008; 3: e1864.

56 Park JK, Henry JC, Jiang J, Esau C, Gusev Y, Lerner MR, et al. miR132 and miR-212 are increased in pancreatic cancer and target the retinoblastoma tumor suppressor. Biochem Biophys Res Commun 2011; 406: 518-23.

57 Mishra PJ, Song B, Mishra PJ, Wang Y, Humeniuk R, Banerjee D, et al. MiR-24 tumor suppressor activity is regulated independent of p53 and through a target site polymorphism. PLoS One 2009; 4: e8445.

58 Song B, Wang Y, Kudo K, Gavin EJ, Xi Y, Ju J. miR-192 Regulates dihydrofolate reductase and cellular proliferation through the p53microRNA circuit. Clin Cancer Res 2008; 14: 8080-6.

59 Shi W, Alajez NM, Bastianutto C, Hui AB, Mocanu JD, Ito E, et al. Significance of Plk1 regulation by miR-100 in human nasopharyngeal cancer. Int J Cancer 2010; 126: 2036-48.

60 Ito T, Sato F, Kan T, Cheng Y, David S, Agarwal R, et al. Polo-like kinase 1 regulates cell proliferation and is targeted by miR-593* in esophageal cancer. Int J Cancer 2011; 129: 2134-46.

61 Butz H, Likó I, Czirják S, Igaz P, Khan MM, Zivkovic V, et al. Downregulation of Wee1 kinase by a specific subset of microRNA in human sporadic pituitary adenomas. J Clin Endocrinol Metab 2010; 95: E181-91.

62 Lee ST, Chu K, Oh HJ, Im WS, Lim JY, Kim SK, et al. Let-7 microRNA inhibits the proliferation of human glioblastoma cells. J Neurooncol 2011; 102: 19-24.

63 Kumar MS, Erkeland SJ, Pester RE, Chen CY, Ebert MS, Sharp PA, et al. Suppression of non-small cell lung tumor development by the let7 microRNA family. Proc Natl Acad Sci U S A 2008; 105: 3903-8.

64 Tsang WP, Kwok TT. The miR-18a* microRNA functions as a potential tumor suppressor by targeting on K-Ras. Carcinogenesis 2009; 30: 953-9.

65 Chen X, Guo X, Zhang H, Xiang Y, Chen J, Yin Y, et al. Role of miR143 targeting KRAS in colorectal tumorigenesis. Oncogene 2009; 28: $1385-92$.

66 Hashimoto Y, Akiyama Y, Otsubo T, Shimada S, Yuasa Y. Involvement of epigenetically silenced microRNA-181c in gastric carcinogenesis. Carcinogenesis 2010; 31: 777-84.

67 Shin KH, Bae SD, Hong HS, Kim RH, Kang MK, Park NH. miR181a shows tumor suppressive effect against oral squamous cell 
carcinoma cells by downregulating K-ras. Biochem Biophys Res Commun 2011; 404: 896-902.

68 Yu S, Lu Z, Liu C, Meng Y, Ma Y, Zhao W, et al. miRNA-96 suppresses KRAS and functions as a tumor suppressor gene in pancreatic cancer. Cancer Res 2010; 70: 6015-25.

69 Liu J, Luo XJ, Xiong AW, Zhang ZD, Yue S, Zhu MS, MicroRNA-214 promotes myogenic differentiation by facilitating exit from mitosis via down-regulation of proto-oncogene N-ras. J Biol Chem 2010; 285: 26599-607.

70 Kent OA, Chivukula RR, Mullendore M, Wentzel EA, Feldmann G, Lee $\mathrm{KH}$, et al. Repression of the miR-143/145 cluster by oncogenic Ras initiates a tumor-promoting feed-forward pathway. Genes Dev 2010; 24: $2754-9$

71 Zhu H, Dougherty U, Robinson V, Mustafi R, Pekow J, Kupfer S, et al. EGFR signals down-regulate tumor suppressors miR-143 and miR-145 in Western diet-promoted murine colon cancer: role of $\mathrm{G}_{1}$ regulators. Mol Cancer Res 2011; 9: 960-75.

72 Hatley ME, Patrick DM, Garcia MR, Richardson JA, Bassel-Duby R, van Rooij E, et al. Modulation of K-Ras-dependent lung tumorigenesis by MicroRNA-21. Cancer Cell 2010; 18: 282-93.

73 Paroo Z, Ye X, Chen S, Liu Q. Phosphorylation of the human microRNA-generating complex mediates MAPK/Erk signaling. Cell 2009; 139: 112-22.

74 Pandey AK, Verma G, Vig S, Srivastava S, Srivastava AK, Datta M. miR-29a levels are elevated in the $d b / d b$ mice liver and its overexpression leads to attenuation of insulin action on PEPCK gene expression in HepG2 cells. Mol Cell Endocrinol 2011; 332: 125-33.

75 Guo C, Sah JF, Beard L, Willson JK, Markowitz SD, Guda K. The noncoding RNA, miR-126, suppresses the growth of neoplastic cells by targeting phosphatidylinositol 3-kinase signaling and is frequently lost in colon cancers. Genes Chromosomes Cancer 2008; 47: 93946.

76 Lin RJ, Lin YC, Yu AL. miR-149* induces apoptosis by inhibiting Akt1 and E2F1 in human cancer cells. Mol Carcinog 2010; 49: 719-27.

77 Watanabe A, Tagawa H, Yamashita J, Teshima K, Nara M, Iwamoto K, et al. The role of microRNA-150 as a tumor suppressor in malignant lymphoma. Leukemia 2011; 25: 1324-34.

78 Foley NH, Bray IM, Tivnan A, Bryan K, Murphy DM, Buckley PG. MicroRNA-184 inhibits neuroblastoma cell survival through targeting the serine/threonine kinase AKT2. Mol Cancer 2010; 9: 83.

79 Roccaro AM, Sacco A, Thompson B, Leleu X, Azab AK, Azab F, et al. MicroRNAs $15 a$ and 16 regulate tumor proliferation in multiple myeloma. Blood 2009; 113: 6669-80.

80 Liu C, Yu J, Yu S, Lavker RM, Cai L, Liu W, et al. MicroRNA-21 acts as an oncomir through multiple targets in human hepatocellular carcinoma. J Hepatol 2010; 53: 98-107.

81 Yamanaka Y, Tagawa H, Takahashi N, Watanabe A, Guo YM, Iwamoto $\mathrm{K}$, et al. Aberrant overexpression of microRNAs activate AKT signaling via down-regulation of tumor suppressors in natural killercell lymphoma/leukemia. Blood 2009; 114: 3265-75.

82 Chun-Zhi Z, Lei H, An-Ling Z, Yan-Chao F, Xiao Y, Guang-Xiu W, et al. MicroRNA-221 and microRNA-222 regulate gastric carcinoma cell proliferation and radioresistance by targeting PTEN. BMC Cancer 2010; 10: 367.

83 Shi W, Gerster K, Alajez NM, Tsang J, Waldron L, Pintilie M, et al. MicroRNA-301 mediates proliferation and invasion in human breast cancer. Cancer Res 2011; 71: 2926-37.

84 Lee DY, Jeyapalan Z, Fang L, Yang J, Zhang Y, Yee AY, et al. Expression of versican $3^{\prime}$-untranslated region modulates endogenous microRNA functions. PLoS One 2010; 5: e13599.

85 Doghman M, El Wakil A, Cardinaud B, Thomas E, Wang J, Zhao W, et al. Regulation of insulin-like growth factor-mammalian target of rapamycin signaling by microRNA in childhood adrenocortical tumors. Cancer Res 2010; 70: 4666-75.

86 Costinean S, Sandhu SK, Pedersen IM, Tili E, Trotta R, Perrotti D, et al. Src homology 2 domain-containing inositol-5-phosphatase and CCAAT enhancer-binding protein beta are targeted by miR-155 in B cells of Emicro-MiR-155 transgenic mice. Blood 2009; 114: 137482.

87 Bhattacharyya S, Balakathiresan NS, Dalgard C, Gutti U, Armistead D, Jozwik C, et al. Elevated miR-155 promotes inflammation in cystic fibrosis by driving hyperexpression of interleukin-8. J Biol Chem 2011; 286: 11604-15.

88 Oneyama C, Ikeda J, Okuzaki D, Suzuki K, Kanou T, Shintani Y, et al. MicroRNA-mediated downregulation of mTOR/FGFR3 controls tumor growth induced by Src-related oncogenic pathways. Oncogene 2011; 30: 3489-501.

89 Merkel O, Hamacher F, Laimer D, Sifft E, Trajanoski Z, Scheideler M. Identification of differential and functionally active miRNAs in both anaplastic lymphoma kinase (ALK)+ and ALK- anaplastic large-cell lymphoma. Proc Natl Acad Sci U S A 2010; 107: 16228-33.

90 Bhatia S, Kaul D, Varma N. Functional genomics of tumor suppressor miR-196b in T-cell acute lymphoblastic leukemia. Mol Cell Biochem 2011; 346: 103-16.

91 Kim JW, Mori S, Nevins JR. Myc-induced microRNAs integrate Mycmediated cell proliferation and cell fate. Cancer Res 2010; 70: 4820-8.

92 Buechner J, Tømte E, Haug BH, Henriksen JR, Løkke C, Flægstad T, et al. Tumour-suppressor microRNAs let-7 and mir-101 target the proto-oncogene MYCN and inhibit cell proliferation in MYCN-amplified neuroblastoma. Br J Cancer 2011; 105: 296-303.

93 Chen Z, Zeng H, Guo Y, Liu P, Pan H, Deng A, et al. miRNA-145 inhibits non-small cell lung cancer cell proliferation by targeting c-Myc. J Exp Clin Cancer Res 2010; 29: 151.

94 Pulikkan JA, Dengler V, Peramangalam PS, Peer Zada AA, MüllerTidow C, Bohlander SK, et al. Cell-cycle regulator E2F1 and microRNA-223 comprise an autoregulatory negative feedback loop in acute myeloid leukemia. Blood 2010; 115: 1768-78.

95 Böhlig L, Friedrich M, Engeland K. p53 activates the PANK1/miRNA107 gene leading to downregulation of CDK6 and p130 cell cycle proteins. Nucleic Acids Res 2011; 39: 440-53.

96 Calin GA, Dumitru CD, Shimizu M, Bichi R, Zupo S, Noch E, et al. Frequent deletions and down-regulation of micro-RNA genes miR15 and miR-16 at 13q14 in chronic lymphocytic leukemia. Proc Natl Acad Sci U S A 2002; 99: 15524-9.

97 Yanaihara N, Caplen N, Bowman E, Seike M, Kumamoto K, Yi M, et al. Unique microRNA molecular profiles in lung cancer diagnosis and prognosis. Cancer Cell 2006; 9: 189-98.

98 Murakami Y, Yasuda T, Saigo K, Urashima T, Toyoda H, Okanoue T, et al. Comprehensive analysis of microRNA expression patterns in hepatocellular carcinoma and non-tumorous tissues. Oncogene 2006; 25: 2537-45.

99 Li W, Xie L, He X, Li J, Tu K, Wei L, et al. Diagnostic and prognostic implications of microRNAs in human hepatocellular carcinoma. Int J Cancer 2008; 123: 1616-22.

100 Iorio MV, Ferracin M, Liu CG, Veronese A, Spizzo R, Sabbioni S, et al. MicroRNA gene expression deregulation in human breast cancer. Cancer Res 2005; 65: 7065-70.

101 Michael MZ, SM OC, van Holst Pellekaan NG, Young GP, James RJ. Reduced accumulation of specific microRNAs in colorectal neoplasia. Mol Cancer Res 2003; 1: 882-91.

102 Schetter AJ, Leung SY, Sohn JJ, Zanetti KA, Bowman ED, Yanaihara 
$\mathrm{N}$, et al. MicroRNA expression profiles associated with prognosis and therapeutic outcome in colon adenocarcinoma. JAMA 2008; 299: 425-36.

103 Petrocca F, Visone R, Onelli MR, Shah MH, Nicoloso MS, de Martino I, et al. E2F1-regulated microRNAs impair TGFbeta-dependent cellcycle arrest and apoptosis in gastric cancer. Cancer Cell 2008; 13 : 272-86.

104 Sempere LF, Christensen M, Silahtaroglu A, Bak M, Heath CV, Schwartz G, et al. Altered microRNA expression confined to specific epithelial cell sub-populations in breast cancer. Cancer Res 2007; 67: 11612-20.

105 Nana-Sinkam SP, Croce CM. MicroRNAs as therapeutic targets in cancer. Transl Res 2011; 157: 216-25.

106 Lan FF, Wang H, Chen YC, Chan CY, Ng SS, Li K, et al. Hsa-let-7g inhibits proliferation of hepatocellular carcinoma cells by downregulation of c-Myc and upregulation of p16(INK4A). Int J Cancer 2011; 128: 319-31.

107 He XY, Chen JX, Zhang Z, Li CL, Peng QL, Peng HM. The let-7a microRNA protects from growth of lung carcinoma by suppression of k-Ras and c-Myc in nude mice. J Cancer Res Clin Oncol 2010; 136: 1023-8.

108 Esquela-Kerscher A, Trang P, Wiggins JF, Patrawala L, Cheng A, Ford L, et al. The let-7 microRNA reduces tumor growth in mouse models of lung cancer. Cell Cycle 2008; 7: 759-64.

109 Yu F, Yao H, Zhu P, Zhang X, Pan Q, Gong C, et al. let-7 regulates self renewal and tumorigenicity of breast cancer cells. Cell 2007; 131: 1109-23.

110 Frezzetti D, De Menna M, Zoppoli P, Guerra C, Ferraro A, Bello AM, et al. Upregulation of miR-21 by Ras in vivo and its role in tumor growth. Oncogene 2011; 30: 275-86.

111 Takeshita F, Patrawala L, Osaki M, Takahashi RU, Yamamoto Y, Kosaka N, et al. Systemic delivery of synthetic microRNA-16 inhibits the growth of metastatic prostate tumors via downregulation of multiple cell-cycle genes. Mol Ther 2010; 18: 181-7.

112 Kota J, Chivukula RR, O’Donnell KA, Wentzel EA, Montgomery CL, Hwang HW, et al. Therapeutic microRNA delivery suppresses tumorigenesis in a murine liver cancer model. Cell 2009; 137: 1005-17.

113 Rao X, Di Leva G, Li M, Fang F, Devlin C, Hartman-Frey C, et al. MicroRNA-221/222 confers breast cancer fulvestrant resistance by regulating multiple signaling pathways. Oncogene 2011; 30: 108297.

114 Miller TE, Ghoshal K, Ramaswamy B, Roy S, Datta J, Shapiro CL, et al. MicroRNA-221/222 confers tamoxifen resistance in breast cancer by targeting p27 ${ }^{\text {kip1 }}$. J Biol Chem 2008; 283: 29897-903.

115 Tomimaru Y, Eguchi H, Nagano H, Wada H, Tomokuni A, Kobayashi $\mathrm{S}$, et al. MicroRNA-21 induces resistance to the anti-tumour effect of interferon- $\alpha / 5$-fluorouracil in hepatocellular carcinoma cells. $\mathrm{Br} \mathrm{J}$ Cancer 2010; 103: 1617-26.
116 Ren Y, Kang CS, Yuan XB, Zhou X, Xu P, Han L, et al. Co-delivery of as-miR-21 and 5-FU by poly(amidoamine) dendrimer attenuates human glioma cell growth in vitro. J Biomater Sci Polym Ed 2010; 21: 303-14.

117 Li Y, Zhu X, Gu J, Dong D, Yao J, Lin C, et al. Anti-miR-21 oligonucleotide sensitizes leukemic K562 cells to arsenic trioxide by inducing apoptosis. Cancer Sci 2010; 101: 948-54.

118 Mei M, Ren Y, Zhou X, Yuan XB, Han L, Wang GX, et al. Downregulation of miR-21 enhances chemotherapeutic effect of taxol in breast carcinoma cells. Technol Cancer Res Treat 2010; 9: 77-86.

119 Li B, Shi XB, Nori D, Chao CK, Chen AM, Valicenti R, et al. Downregulation of microRNA $106 \mathrm{~b}$ is involved in p21-mediated cell cycle arrest in response to radiation in prostate cancer cells. Prostate 2011; 71: 567-74.

120 Yan D, Ng WL, Zhang X, Wang P, Zhang Z, Mo YY, et al. Targeting DNA-PKCs and ATM with miR-101 sensitizes tumors to radiation. PLoS One 2010; 5: e11397.

121 Chen Q, Chen X, Zhang M, Fan Q, Luo S, Cao X. miR-137 is frequently down-regulated in gastric cancer and is a negative regulator of Cdc42. Dig Dis Sci 2011; 56: 2009-16.

122 Chien WW, Domenech C, Catallo R, Kaddar T, Magaud JP, Salles G, et al. Cyclin-dependent kinase 1 expression is inhibited by $\mathrm{p} 16^{\text {INK4a }}$ at the post-transcriptional level through the microRNA pathway. Oncogene 2011; 30: 1880-91.

123 Herrera-Merchan A, Cerrato C, Luengo G, Dominguez O, Piris MA, Serrano M, et al. miR-33-mediated downregulation of p53 controls hematopoietic stem cell self-renewal. Cell Cycle 2010; 9: 3277-85.

124 Guo X, Guo L, Ji J, Zhang J, Zhang J, Chen X, et al. miRNA-331-3p directly targets E2F1 and induces growth arrest in human gastric cancer. Biochem Biophys Res Commun 2010; 398: 1-6.

125 Lang N, Liu M, Tang QL, Chen X, Liu Z, Bi F. Effects of microRNA-29 family members on proliferation and invasion of gastric cancer cell lines. Chin J Cancer 2010; 29: 603-10.

$126 \mathrm{Hu} \mathrm{H}$, Du L, Nagabayashi G, Seeger RC, Gatti RA. ATM is downregulated by N-Myc-regulated microRNA-421. Proc Natl Acad Sci U S A 2010; 107: 1506-11.

127 Wang P, Zou F, Zhang X, Li H, Dulak A, Tomko RJ Jr, et al. microRNA21 negatively regulates Cdc25A and cell cycle progression in colon cancer cells. Cancer Res 2009; 69: 8157-65.

128 Zhang Y, Chao T, Li R, Liu W, Chen Y, Yan X, et al. MicroRNA-128 inhibits glioma cells proliferation by targeting transcription factor E2F3a. J Mol Med 2009; 87: 43-51.

129 Tian S, Huang S, Wu S, Guo W, Li J, He X. MicroRNA-1285 inhibits the expression of p53 by directly targeting its $3^{\prime}$ untranslated region. Biochem Biophys Res Commun 2010; 396: 435-9.

$130 \mathrm{Hu} \mathrm{W}$, Chan CS, Wu R, Zhang C, Sun Y, Song JS, et al. Negative regulation of tumor suppressor p53 by microRNA miR-504. Mol Cell 2010; 38: 689-99. 